NBER WORKING PAPER SERIES

AGE-BASED PROPERTY TAX EXEMPTIONS

H. Spencer Banzhaf

Ryan Mickey

Carlianne E. Patrick

Working Paper 25468

http://www.nber.org/papers/w25468

\author{
NATIONAL BUREAU OF ECONOMIC RESEARCH \\ 1050 Massachusetts Avenue \\ Cambridge, MA 02138 \\ January 2019, Revised October 2020
}

This work was supported by the Center for State and Local Government Finance at Georgia State University. The Center for State and Local Government Finance was not involved in the research design, data collection, analysis, interpretation, or writing. The authors are solely responsible for work. The views expressed herein are those of the authors and do not necessarily reflect the views of the National Bureau of Economic Research.

NBER working papers are circulated for discussion and comment purposes. They have not been peer-reviewed or been subject to the review by the NBER Board of Directors that accompanies official NBER publications.

(C) 2019 by H. Spencer Banzhaf, Ryan Mickey, and Carlianne E. Patrick. All rights reserved. Short sections of text, not to exceed two paragraphs, may be quoted without explicit permission provided that full credit, including $\odot$ notice, is given to the source. 
Age-Based Property Tax Exemptions

H. Spencer Banzhaf, Ryan Mickey, and Carlianne E. Patrick

NBER Working Paper No. 25468

January 2019, Revised October 2020

JEL No. H7,R2

\begin{abstract}
$\underline{\text { ABSTRACT }}$ of different tax policies.

H. Spencer Banzhaf

Department of Economics

Andrew Young School of Policy Studies

Georgia State University

P.O. Box 3992

Atlanta, GA 30302

and NBER

hsbanzhaf@gsu.edu

Ryan Mickey

Maryville College

1013 Makena Cove Way

Knoxville, TN 37909

ryan.mickey@maryvillecollege.edu

Carlianne E. Patrick

Department of Economics

PO Box 3992

Atlanta, GA 30302-3992

cpatrick@gsu.edu
\end{abstract}

Many local jurisdictions offer property tax exemptions or similar concessions to older citizens. Such exemptions represent substantial intergenerational transfers and may have important implications for local public finances. The consequences of age-based property tax exemptions depend upon the extent to which they influence households' location decisions, housing tenure decisions, and housing consumption. We provide the first evidence on (long-term) changes in household composition and housing consumption attributable to local, age-based property tax exemptions. We construct a unique database of local property tax exemptions in Georgia covering 100 years of county, school district, and selected city property tax laws. We use these data to estimate the effect of age-based property tax exemptions on the number of older homeowners from 1970-2010 attributable to the exemption. Using a "quadruple-difference" estimation strategy, we find a significant increase in older homeowners attributable to the combined effect of age-based property tax exemptions on location decisions and housing tenure. We also find evidence that age-based property tax exemptions increase housing consumption among older households. Finally, we estimate a sorting model to estimate the equilibrium effects

A data appendix is available at http://www.nber.org/data-appendix/w25468 


\title{
Age-Based Property Tax Exemptions
}

\author{
H. Spencer Banzhaf, Ryan Mickey, and Carlianne Patrick
}

\section{Introduction}

As the largest single source of revenue for state and local governments in the United States, property taxes are a primary funding mechanism for local public goods and services. Yet this tax base has eroded over time, as local governments enact exemptions, abatements, and other concessions (Augustine et al. 2009). Age-based property tax exemptions are part of this trend. Across the United States, many local jurisdictions offer property tax exemptions or similar concessions to older citizens, especially from taxes supporting school districts.

Such exemptions first attracted the attention of tax professionals some fifty years ago (e.g., Chen 1965), but they have become much more widespread in recent decades. For example, in the state of Georgia, in 1970 only about 5\% of the population lived in a local jurisdiction with some kind of age-based property tax exemption, whereas today it is more than $80 \%$ (though they vary in generosity and the population covered). As of 2018, 20 states and the District of Columbia provide some level of property tax exemption or credit for seniors, and six give local jurisdictions the option of increasing the exemptions generosity. Further, an additional ten states give local jurisdictions the option of providing these exemptions. In addition to the exemptions and credits, thirty-nine states have at least one program for seniors to defer property taxes, freeze assessments or property taxes, or property tax circuit breaker (Lincoln Institute 2020).

Such exemptions are controversial. For example, in suburban Atlanta, Cobb County has made headlines for its generous exemption from the education property tax for seniors at a time when schools' budgets have been severely squeezed (Davis 2010, Downey 2013). Defenders of age-based exemptions argue that housing makes up a larger share of the budget for older households, that many older households paid into the community for many years, and that most presently do not have children in the schools. From this perspective, exemptions effectively reduce the public service subsidies from older households (Shan 2010, Gallagher et al. 2018). Additionally, age-based exemptions may help older residents remain in their homes, increasing neighborhood stability. Critics point out that, on the other hand, most older households do not have mortgages, 
that they benefit from the increased housing values associated with strong schools and other public services, that other households with no children in the schools are not exempted, and that today's seniors benefited when they were younger from receiving the payments of the previous generation of older households.

In addition to their direct effect on the tax base, age-based property tax exemptions may also have unintended consequences in the form of changes in jurisdictional household composition and changes in housing values. These changes could, in turn, have a "dynamic scoring" effect on local public finances. That is, the effect of senior discounts on local public finances may be different in the long run if the discounts increase the share of older homeowners. Recently, Gallagher et al. (2018) examined the effect on local school finances of an exogenous increase in the population of older households. They consider two effects, the tax base effect, which represents the transfer of resources from households without school-age children, and the tax rate effect, as the political process generates lower tax rates (for all households) in jurisdictions with more older households. They find the former effect dominates. However, they do not consider the effect of age-targeted tax exemptions, which essentially represent a way to reduce the tax base effect.

The decrease in the cost of homeownership in a particular location granted by age-based property tax exemptions potentially influences eligible households through three channels. First, age-based exemptions could affect the location decision of older homeowners, as they have an incentive to move to areas with more generous exemptions (or refrain from moving away). Second, such exemptions similarly could affect the tenure decision of older homeowners, as they have more incentive to own their property than to rent. Third, at the intensive margin, the tax subsidies could induce older homeowners to consume more housing, much like the mortgage income tax deduction (Hanson 2012). Tiebout sorting and migration studies provide mixed evidence regarding the effect of taxes and public goods on the location decisions of older households, but there is substantial evidence that households generally move in response to changes along these dimensions. There is less evidence on the potential for age-based exemption-induced increases on the extensive margin in the number of households owning a home and on the intensive margin in the size of the house, or amount of housing capital.

To our knowledge, this paper is the first to provide evidence on the effect of local age- 
based property tax laws on local changes in household composition through the differential location and tenure decisions of older households as well as the effect on housing consumption. To do so, it uses a unique, newly constructed database of local property tax exemptions in Georgia. The data cover 100 years of county, school district, and selected city property tax laws. We use these data to estimate the effect of age-based property tax exemptions on the percentage change in the number of older homeowners from 1970-2010 that is attributable to the exemption.

We use a "quadruple-difference" estimation strategy that uses counterfactual information from jurisdictions without exemptions as well as young owners and older renters in the treated counties to identify the effect on older homeowners. Computationally, we estimate difference-indifferences, looking at changes in the demographics of counties that adopt age-based property taxes relative to changes in counties that didn't. However, relative to a standard difference-indifferences model, we allow the residuals to be correlated with differential trends in renters and younger owners. That is, it does not require parallel trends in all four groups, but in the differences among groups. For example, age-based exemptions may come to areas that are growing older, but if the correlation is similar for older renters and older owners, that correlation cancels out in the differencing. Furthermore, to address potential concerns of simultaneity between demographic trends and policy changes, we also repeat this approach using changes in population as a response to lagged policies.

In addition, we estimate the change in counties' mean housing values using a triple-difference strategy. The strategy is similar to the demographic model but ignores renters. Finally, we implement a more structural approach to estimate the effect of the policies on local populations. This model has stronger econometric assumptions but lends itself to more straightforward interpretations within an equilibrium model of locational choice.

We find a significant increase in older homeowners attributable to the combined effect of age-based property tax exemptions on location decisions and housing tenure. A ten percent increase in county households residing in a jurisdiction with age-based exemptions causes a 4-6 percent increase in the number of older homeowners, net of the change in untreated counties, relative to the change in older renters and younger households in treated counties. These estimates are generally stable over a range of specifications, including controls for the intensity of the exemption. 
These reduced form estimates require relatively weak econometric assumptions. However, one may still be concerned about whether they identify an effect solely for older owners, or whether, by eroding the local tax base, there are effects on all demographic groups. In that case, we can still interpret the reduced form estimates as a causal effect, on demographic compositions. For that reason, we view them qualitatively, as statistical evidence of an effect of the taxes on local demographic compositions. Then, to better interpret the results in an economic framework, we supplement these results by explicitly modeling substitution patterns with a structural model. There, we find both older and younger owners are attracted by the policy. We further find that exemptions induce increases in housing consumption by older households. Taken as a pair, the quadruple-difference and the locational choice model provides strong evidence that households are sorting on local tax variables. Finally, we find that in a counterfactual world where Cobb County (with Georgia's most generous exemptions for the elderly) had not enacted the policy, the population of older homeowners would be lower by an amount equal to 3-5\% of the County's population.

Previous work on the sorting and migration of older households has focused on inter-state migration, which our work extends to the local (intra-state) sale. Conway and Rork (2006) examine interstate migration of older households and find little effect of state taxes on estates, inheritances, and gifts. Similarly, Conway and Rork (2012) find little effect of age-based income tax breaks. On the other hand, Moretti and Wilson (2020) find a large effect of state estate taxes on the location of billionaires, but only after the federal government eliminated its tax credit for state estate taxes. Önder and Schlunk (2019) find that older households are more likely to move to states that provide sales tax exemptions on items more frequently purchased by older households than young households. Gale and Heath (2000) explicitly model the endogeneity of elderly migration and state fiscal policy in their analysis and find that states with higher average property taxes have less net in-migration.

Several other papers have used Health and Retirement Survey (HRS) data on self-reported property tax payments when considering migration decisions. Seslen (2005) examines the effect of property taxes on the decision of older households to downsize and finds little evidence that property taxes influence the decision to move or liquidate their housing. Farnham and Sevak (2006) find that recent empty-nesters reduced their exposure to property taxes when moving across state lines, but not when moving within states, suggesting that households may consider this factor 
when making a move. Shan (2010) uses more recent data from the HRS and instruments for property tax payments with variation in state-provided property tax relief programs. She finds that higher property taxes do increase the housing mobility of older households, causing them to downsize or move to states with lower property taxes, with state-provided property tax relief programs diminishing that mobility.

In addition to the specific policy question of age-based tax exemptions, our results provide additional general evidence that households sort or vote based on tax burdens, conditional on amenities (Oates 1969, Palmon and Smith 1998, Banzhaf and Oates 2013, MacKay 2014, Stadelmann and Eichenberger 2014). Moulton, Waller, and Wentland (2018) have specifically found that age-based tax exemptions in Virginia increase property values, indicating an overall demand shock, but do not consider demographic sorting patterns or housing consumption explicitly.

The paper proceeds in the next section by outlining our empirical strategy. We detail the local property tax exemptions and describe the Georgia Property Tax Data Base in Section 3. Section 4 summarizes trends in the data and our main results. Section 5 concludes.

\section{Empirical Strategy}

As noted above, we expect age-based property tax exemptions to affect the locational decisions of older households, their housing tenure, and their housing consumption. Unfortunately, we do not observe moves (by age and tenure) directly, but only repeated snapshots of the population by age and tenure and the owner-occupied housing stock by age. Accordingly, we group the first two as a combined effect at the extensive margin, which we call the older homeowner effect. We consider these effects separately from the housing consumption effect at the intensive margin.

\subsection{The Older Homeowner Effect}

If age-based property tax exemptions affect the locational decisions of older homeowners and their housing tenure decisions, we would expect to find more older homeowners in counties with more generous exemptions, relative both to older renters and to younger homeowners, ceteris paribus. To minimize possible threats to identification caused by unobservables coincident to the adoption of age-based property tax exemptions and to migratory and housing decisions, we use a 
"quadruple-difference" strategy. In particular, we define four categories of household demographic types: older homeowners, older renters, young homeowners, and young renters. We then estimate the logged number of households of demographic category $i$ living in jurisdiction $j$ at decade $t$ (from 1970 to 2010) by:

$$
\begin{aligned}
\ln y_{i j t}= & \gamma_{0}+\gamma_{1} 1(\text { Older })_{i}+\gamma_{2} 1(\text { Owner })_{i}+\gamma_{3}[1(\text { Owner }) \times 1(\text { Older })]_{i} \\
& +\gamma_{4} \text { Treatment }_{j t} \\
& +\gamma_{5}[1(\text { Older }) \times \text { Treatment }]_{i j t} \\
& +\gamma_{6}[1(\text { Owner }) \times \text { Treatment }]_{i j t} \\
& +\gamma_{7}[1(\text { Owner }) \times 1(\text { Older }) \times \text { Treatment }]_{i j t}+\alpha_{j}+\mu_{t}+\varepsilon_{i j t}
\end{aligned}
$$

where Treatment $_{j t}$ is one of the age-based treatment variables discussed in more detail below, which indicate whether county $j$ has an aged-based exemption at time $t, 1$ (Older) $)_{i}$ is a dummy variable for whether treatment group $i$ is for households aged 65 and older, $1(\text { Owner })_{i}$ is an indicator variable equal to one if treatment group $i$ involves homeowners, $\alpha_{j}$ is a vector of county fixed effects, and $\mu_{t}$ is the vector of time fixed effects.

Our coefficient of interest is $\gamma_{7}$, the coefficient on the interaction term [1(Owner $) \times$ 1 (Older $) \times$ Treatment $_{i j t}$. This term represents a "quadruple-difference." To see this, note that if we omitted the terms for $\gamma_{5}, \gamma_{6}$, and $\gamma_{7}$, the standard difference-in-differences (DD) estimate would be $\gamma_{4}$, the coefficient on our treatment variable, which differs by jurisdiction and time (as represented by fixed effects $\alpha_{j}$ and $\mu_{t}$ ). The DD therefore is identified from the before/after and between-county variation in treatment. However, because we have specified heterogeneous effects along the age and tenure dimensions, in our model $\gamma_{4}$ represents the DD for young renters. In principle, Equation (1) estimates four difference-in-differences, as summarized in Table 1 by the four upper-left cells. ${ }^{1}$ Our strategy compares the difference between the DD for older owners and older renters (i.e. $\gamma_{6}+\gamma_{7}$ ) to the difference between the DD for younger owners and younger renters (i.e. $\gamma_{6}$ ). This quadruple difference is $\gamma_{7}$. Equivalently, we could define this as the difference between the DD for older owners and younger owners (i.e. $\gamma_{5}+\gamma_{7}$ ) to the difference between

\footnotetext{
${ }^{1}$ Note it estimates these simultaneously, so differs from estimating four difference-in-differences regressions separately insofar as some control parameters are constrained to be equal across groups.
} 
the DD for older and younger renters (i.e. $\gamma_{5}$ ). Again, the difference is $\gamma_{7}$.

This empirical strategy requires fairly weak assumptions to interpret $\gamma_{7}$ as the effect of the property tax exemptions on older homeownership in the treated counties. Most generally, it allows for the possibility that changes in age-based property tax exemptions occur at the same time as other unobserved changes that influence population, homeownership, or even particular age groups. It simply requires that any unobservable changes coincident to the policy (in time and space) do not attract older owners, relative to older renters, differently than they attract younger owners, relative to younger renters. This requirement is weaker than the assumption that such effects are identical for our four demographic groups. In other words, just as a standard differencein-difference does not require identifying all four cells, our quadruple-differences strategy does not rely on identification of all four difference-in-difference estimates. Only the relative comparisons need to be identified.

Second, our approach assumes that any one county's age-based property tax exemption does not have a significant effect on the outcomes of other counties. In other words, we do not need to rule out general equilibrium effects as a whole from the policy: only general equilibrium effects from one average county.

Third, our approach allows for the possibility of some types of effects on other groups. In particular, decreasing the tax base may have an effect not only on older households but all residents of the community. For example, maybe a decline in tax revenues decreases the maintenance of county roads or parks. If all four groups value roads or parks equally, then these effects will cancel out in the quadruple difference.

More challenging is the case where other groups are affected differentially from older owners. We cannot rule out such effects a priori. First, the lost revenue may be made up by taxing others (e.g. young owners) more, maintaining the level of public expenditure. Alternatively, if other taxes are held constant, the level of public expenditure will decline, but in contrast to our discussion above of roads or parks, it may hit a category like public schools valued more by younger residents (with children in school). ${ }^{2}$ In this case, our quadruple-difference results should

\footnotetext{
${ }^{2}$ For small changes, around the optimal point where $\$ 1$ per capita of public expenditure is worth $\$ 1$ of private expenditure) to people, it should not matter which side of the coin the effect comes, whether through higher taxes (and hence lower private expenditure) or lower public expenditure.
} 
probably best be viewed as statistical evidence of an effect of tax exemptions on overall population compositions, rather than a causal effect on older owner populations alone. Accordingly, as discussed below, we supplement this analysis with a structural model that, while requiring stronger assumptions, yields results that are easier to interpret.

We also present reduced form estimates that rely on even weaker assumptions. Specifically, our base models, presented below, augment Equation (1) with yearXolder and yearXowner effects. Further, we present estimates that include exemption-year and exemption-county interactions. This controls for the potentially heterogeneous effects of a law on a particular county (independent of the demographic group) and likewise in a particular decade. We also present results from a specification that adds exemption-year, exemption-county, county-age, county-owner, owner-year, and year-age-urban status interactions to Equation (1). ${ }^{3}$ This model controls for potentially heterogeneous effects of the law in a particular county or decade as well as county-level demographic trends, and any general rural-urban migration tendencies by age group in a particular decade.

Naturally, one potential concern with our analysis is the possible simultaneity between demographic compositions and age-specific tax exemptions. We address this concern in two ways. First, we explore pre-trends in the demographic compositions across counties, using a new approach for dynamic treatment effects in event studies proposed by Sun and Abraham (2020). We find relatively flat pre-trends in the quadruple difference. Second, as an alternative, we consider models in which the dependent variable is the percentage change in the population of the demographic group over a decade, which is a function of the lagged policy at the beginning of the decade. By including county or county-age fixed effects, these models control for long-run county-by-demographic-group time trends (which now absorb the average percentage change for each group). Thus, they reduce the potential for simultaneity, as any such concerns would have to be based on forecasting future shocks to demographic composition away from long-term trends. Unfortunately, these models are quite demanding of the data, as they require picking up "tilting" in the population growth curves at the time of adoption, even when responses may be sluggish.

\footnotetext{
${ }^{3}$ Counties are defined as urban if their USDA rural-urban continuum code was 1-3 in 1974.
} 


\subsection{The Housing Consumption Effect}

In addition to these locational and tenure effects, we also consider the effect of the policy on housing consumption using mean housing values by age. However, because our housing value data is available for owner-occupied units only, we substitute a "triple-difference" strategy for the quadruple-difference strategy outlined above, essentially dropping all terms involving renters. Specifically, we estimate the logged mean housing value for households of demographic type $i$, $i \in\{$ Young, Older $\}$, living in jurisdiction $j$ at time $t, y_{i j t}$, by:

$$
\begin{aligned}
\ln y_{i j t}= & \left.\pi_{0}+\pi_{1} 1 \text { (Older }\right)_{i}+\pi_{2} \text { Treatment }_{j t}+\pi_{3}[1 \text { (Older }) \times \text { Treatment }_{i j t} \\
& +\alpha_{j}+\mu_{t}+\varepsilon_{i j t} .
\end{aligned}
$$

Our parameter of interest is $\pi_{3}$, the difference in the mean home value of older households after the implementation of age-based property tax exemptions compared to the difference in mean home values for young households in treated counties relative to this difference in untreated counties. We can interpret $\pi_{3}$ as the causal effect of the policy on older homeowners' housing consumption in treated counties under the assumption that any unobserved changes in treated county home values either caused by or coincident to the exemption do not differentially affect homeowners on the basis of age. That is, if both demographic groups face the same function mapping size and quality of housing into housing values, then higher values must imply a larger or higher-quality house. $^{4}$

Again, we also present estimates that control for potentially heterogeneous effects in each county and decade by replacing the county and decade fixed effects with exemption-year and exemption-county interactions. We also present results from a specification that add exemptionyear, exemption-county, county-age, year-age, and year-urban status interactions to control for potentially heterogeneous effects of the law in a particular county or decade as well as countylevel age trends and any rural-urban migration tendencies by age group in a particular decade.

\footnotetext{
${ }^{4}$ Note, however, that we cannot rule out the possibility that there is a causal effect on the overall price function, such as those found by Moulton, Waller, and Wentland (2018). Such effects would be differenced out in the comparison between older and younger households.
} 
Finally, we consider percentage changes in housing value as the dependent variable, again essentially controlling for county-by-age time trends in housing consumption.

\subsection{A Structural Model}

The strategy outlined in Sections 2.1 and 2.2 is useful for determining a causal effect of the tax policies on overall population compositions. However, both because of the differencing strategy and because it does not explicitly model substitution patterns, the causal strategy is less useful for predicting the actual effects of tax policies on local populations. As discussed above, it is plausible that other demographic groups are affected in ways that do not cancel out in the quadruple difference, making it difficult to know if the net effect we've identified is only the effect for older owners or a relative effect.

To better interpret these results in an economic framework, we add more structure, modeling people's choices using a simple sorting model (e.g. Kuminoff, Smith, and Timmins 2013). Allowing for heterogeneity by age, we assume each household chooses tenure $\tau$ and location $j$ (2x $J$ choice alternatives) based on its utility for each alternative. In particular, we assume choices are based on the following random utility model:

$$
\begin{aligned}
u_{i j \tau t}= & \beta_{1} \text { Treatment }_{j t}+\beta_{2}\left[1\left(\text { Older }_{i}\right) \times \text { Treatment }_{j t}\right]+\beta_{3} \text { Own }_{\tau} \\
& +\beta_{4}\left[1\left(\text { Older }_{i}\right) \times \text { Own }_{\tau}\right]+\beta_{5}\left[1\left(\text { Own }_{\tau}\right) \times \text { Treatment }_{j t}\right] \\
& +\beta_{6}\left[1\left(\text { Older }_{i}\right) \times 1\left(\text { Own }_{\tau}\right) \times \text { Treatment }_{j t}\right]+\alpha_{j} \\
& \left.+\beta_{7 t}\left[1 \text { Older }_{i}\right) \times 1\left(\text { Urban }_{j}\right)\right]+\varepsilon_{i j t} .
\end{aligned}
$$

That is, we assume people have utility for a county/tenure pair that can be explained by the county's treatment status (or factors correlated with the treatment common to both age groups), whether the choice alternative represents owning or renting, an interaction for between treatment and owning, and a county fixed effect. We allow for heterogeneity in tastes for these factors by older/younger households, which we incorporate through interaction with an older dummy. We also interact tastes for an urban county by age, and allow these differential tastes for urban to vary over time.

Due to data limitations, we do not include housing prices. However, these can be thought to be absorbed in the county dummies and in $\beta_{1}$. As long as older and younger households face the same prices within a county, missing housing prices should not bias the estimates of $\beta_{6}$. The 
random component of utility is assumed to be distributed iid logit. Thus, the model can be estimated using a conditional logit model.

\section{Data}

This section introduces the data used in our analysis, including the data we collected on local tax exemptions in Georgia.

\subsection{The Georgia Property Tax Database}

We collected and coded data on local residential property tax laws in Georgia, creating the Georgia Property Tax Database. ${ }^{5}$ This database details the variability in homestead exemptions across local jurisdictions in Georgia as well as the variability within a jurisdiction by individual characteristics, including age, disability status, veteran status, and income. This unique data set covers a one hundred year period, from 1913 to 2013. ${ }^{6}$ We include four types of jurisdictions in the database: (i) all 159 counties; all school districts, which we subdivide into (ii) all 159 countylevel school districts and (iii) the state's 26 independent school districts; and (iv) select municipalities, including the top 30 most populated cities in Georgia plus others with an independent school district.

The database provides information on up to eight local property tax rules and eight state rules for each jurisdiction and year, with details on the demographic group to whom the property tax provision is targeted, including age and income limits (and combinations of the two).

The data are organized using the following conceptual framework. In the absence of any local property tax concessions, the total ad valorem property tax for a household of demographic type $i$ living in jurisdiction $j$ (levied by jurisdiction $j$ ) is given by:

$$
T_{i j}=\left(\tau_{j}^{M O}+\tau_{j}^{B}\right) \beta_{j} V
$$

\footnotetext{
${ }^{5}$ A summary and discussion of the data used here has previously been published in Banzhaf, Mickey, and Patrick (2016), from which this summary draws heavily. The Georgia Property Tax Database is housed at Georgia State University's Fiscal Research Center. For documentation and information about obtaining the data, see http://frc.gsu.edu/data-collections/.

${ }^{6}$ Although the first recorded property tax exemption in the state is a state level exemption in 1938, we confirmed the absence of property tax exemption laws during the period from 1913-1938.
} 
where $V$ is the fair market value, $\beta_{j}$ is the assessment ratio in jurisdiction $j$, and $\tau^{M O}$ and $\tau^{B}$ are, respectively, the property tax rates for maintenance and operations and for bonds.

Exemptions and concessions may reduce some households' total ad valorem tax either by altering the taxable value or the tax rate. Incorporating various exemptions and other concessions into Equation (4), the ad valorem tax for a household of demographic type $i$ living in jurisdiction $j$ becomes:

$$
T_{i j}=\theta_{i j}^{M O} \tau_{j}^{M O}\left(\phi_{i j}^{M O} \beta_{j} V-\left(\delta_{S i j}^{M O}+\delta_{L i j}^{M O}\right)\right)+\theta_{i j}^{B} \tau_{j}^{B}\left(\phi_{i j}^{B} \beta_{j} V-\left(\delta_{S i j}^{B}+\delta_{L i j}^{B}\right)\right),
$$

with the restriction that $T_{i j} \geq 0$. This expression uses the following notation:

$\theta_{i j}^{M O}$ and $\theta_{i j}^{B}$ are the proportions by which the $\mathrm{M} \& \mathrm{O}$ and bond millage rates, respectively, are prorated ( 0 being a full exemption) for individual $i$ in jurisdiction $j$;

$\phi_{i j}^{M O}$ and $\phi_{i j}^{B}$ are the respective proportionate adjustments to the assessment ratio;

$\delta_{S i j}^{M O}$ and $\delta_{S i j}^{B}$ are the respective dollar amounts of the state exemption, which in some cases may differ by jurisdiction and individual; and

$\delta_{L i j}^{M O}$ and $\delta_{L i j}^{B}$ are the respective dollar amounts of an applicable local exemption.

Using these definitions, $\beta_{j} V$ is the assessed value and $\phi_{i j}^{M O} \beta_{j} V-\left(\delta_{S}^{M O}+\delta_{L i j}^{M O}\right)$ is the net assessed value. By some definitions only the $\delta$ terms would be considered exemptions, but as a convenient shorthand we refer to the full range of concessions (including $\theta$ and $\phi$ as well as $\delta$ ) as "exemptions."

Merged with data on millage rates (available 1990-2013), these data allow one to simulate how much property tax an individual household of a given demographic category would pay in property taxes in a given jurisdiction, in a given year, on a property with a specified assessed value (assuming the household takes advantage of all exemptions available). For example, suppose in a particular county that $\tau_{j}^{B}=0$ so we need only be concerned with taxes on M\&O. Suppose a house has a fair market value of $V=\$ 200,000$ and has an assessment ratio $\beta_{j}=0.4$. Suppose all households regardless of demographic group receive the state exemption of $\delta_{S i j}^{M O}=\$ 2,000$. Suppose that households under age 65 can take an additional local exemption $\delta_{L i j}^{M O}=\$ 10,000$ but households 
over age 65 can instead take a proportionate adjustment on its property taxes of $\theta_{i j}^{M O}=0.5$. Finally suppose the millage rate is $\tau_{j}^{M O}=20$ mills, or 2 percent. Using Equation (5), a younger taxpayer would pay $20 *(0.4 * \$ 200,000-\$ 2,000-\$ 10,000) / 1000=\$ 1,360$. In contrast, an older taxpayer would pay $0.5 * 20 *(0.4 * \$ 200,000-\$ 2,000) / 1000=\$ 780$.

\subsection{Treatment}

As discussed above, our unique data include details on local property tax exemptions for county, county schools, city schools, and selected cities. The unit of observation for our outcomes is the county. Therefore, we must aggregate our jurisdiction-level exemptions data to the county level. ${ }^{7}$ In practice, we use two measures of treatment across jurisdictions within a county.

The first measure is a simple housing unit weighted average of indicator variables denoting any treatment in the county and selected cities at time $t$. The county indicator equals one if either the county or the county school district has an aged-based property tax law. The city indicator equals one if either the city or its independent school district has such a law. We then aggregate these dummies up to the county level. If no jurisdiction (for which we have exemption data) within county $j$ has an age-based exemption at time $t$, then this measure is equal to 0 . This measure is equal to 1 if either the county or the county school district has an age-based property tax exemption at time $t$, with no income test. In cases where there are city but no county-wide age-based exemptions, we use the housing unit weighted average of the city and county indicators, giving a measure on the unit interval. Additionally, in cases where there is an income test, we further assigned the treatment to the unit interval, using the proportion of the state's population meeting the income test in that year. (Using the state's population assures that the treatment is exogenous to the local demographic composition.) Thus, for example, if the county jurisdictions had no age-based exemption but the county had a city, with half the county's population, with an exemption that included an income test which half the state's population would meet, we would assign the county a

\footnotetext{
${ }^{7}$ Ideally, we would control for local population conditions, such as whether one group or another lives in a particular urban portion within a county. To address such issues, we rely on our quadruple-difference strategy, which still embeds the usual before/after and treated/untreated comparisons of a standard difference-in-difference. Consequently, if elderly people generally live, e.g., in older rural neighborhoods relative to younger people, it would not raise econometric difficulties. They would have to live in such neighborhoods differentially after the tax reform than before, in those counties with stronger reforms relative to those with weaker.
} 
treatment value of $0.25=0.5^{*} 0.5$.

Our first measure has a straightforward interpretation as the weighted average of households in county $j$ at time $t$ that are eligible for an age-based property tax exemption (i.e., the housing unit weighted dosage of any treatment in the county). However, it does not adjust for the intensity of the treatment. For example, the treatment indicator equals one for a county with a county school district exemption and no county government exemption. If the county government adopts an agebased exemption in the subsequent period, then this measure does not change to reflect the increase in benefits associated with the county exemption.

In order to represent the intensity of age-based property tax exemption in each jurisdiction, we also consider the housing unit weighted ratio of simulated average property taxes for households under 65 and over 65 . We first simulate the average tax for households with a head aged under 65 and over 65 for each jurisdiction and year in our sample, as described in more detail below. We then find the county average for each age group as the housing-unit weighted average across the county and any included cities. Our final measure is 1 minus the ratio of the over-65 average simulated property tax bill to the under- 65 , so that the measure is on $[0,1]$ and increasing in the discount for older households.

We simulate the average tax for households in each covered taxing jurisdiction as follows. First, we randomly sampled 1,000 households residing in Georgia from the IPUMS micro data for each of the years 1970, 1980, 1990, 2000, and 2010. Next, we calculate each individual's property taxes, for each of the tax jurisdictions, after applying the various state and local property tax exemptions for which the household is eligible, and combining property taxes across jurisdictions (county, city, school district) into the property tax bill. In calculating these taxes, we assume each household takes the most generous exemption from the state or the local jurisdiction for which they meet the eligibility criteria. We allow the combination of two exemptions as long as the specific exemptions allowed it. That is, we calculate the household's property tax in each jurisdiction assuming that the household understands the optimal exemption choices for minimizing their property tax bill and that households take the necessary steps to take advantage of the optimal 
choice. $^{8}$

Because house values, assessment ratios, and millage rates are likely endogenous in our context, we use "typical" values for these variables across all jurisdictions. We calculated the typical house value for each decade by aggregating county value level data and taking the mean. The assessment ratio to determine the taxable amount for a house value was standardized to $40 \%$, the legal ratio set by the state. ${ }^{9}$ We set the typical millage rate as the housing-unit weighted mean of all jurisdictions in the state in 2000 , or 13.2 mills.

Using the simulated property taxes of each household for each jurisdiction in each year, we found the average tax for each jurisdiction-year pair for two groups: those households with heads under 65 years old and households with heads 65 or older. This effectively tells us how generous the exemptions are for older households compared to younger. We then aggregated the average property taxes for the two groups across jurisdictions in the county using city-county housing unit weights. Finally, we take the negative of the ratio of the weighted average bill for households 65 or older to the weighted average bill for households under 65 and use this as our intensity-adjusted measure of treatment.

\subsection{Trends in Age-Based Property Tax Exemptions}

Table 2 presents the percentage of each jurisdiction with an age-specific property tax exemption in the four decades that we study. It reveals two important patterns. First, although all types of local governments in Georgia offer age-based property tax exemptions, school districts are much more likely to do so than counties or municipalities. For example, in 2010, 54.7\% of county school districts and $61.5 \%$ of city school districts offered such exemptions compared to $41.5 \%$ of counties and $36.9 \%$ of cities. Second, regardless of jurisdiction type, age-targeted tax exemptions among Georgia's local governments have increased over time. Indeed, only the rare

\footnotetext{
${ }^{8}$ One potential concern is that households do not actually take the steps necessary to realize their exemptions. As discussed in Banzhaf, Mickey, and Patrick (2016), our analysis of the take-up rate in the Georgia county offering the most generous exemption indicates that approximately $96 \%$ of households get their exemption. However, we acknowledge the potential for error in that calculation as well as the possibility that take-up rates are a function of the generosity of the benefit. We believe take-up rates between $90 \%-100 \%$ to be reasonable, which is consistent with a 1990's study by the AARP that found take-up rates of approximately $90 \%$ for homestead exemptions (Baer 1990).

${ }^{9}$ O.C.G.A. 48-5-7 set the assessment ratio at $40 \%$ for all Georgia tax jurisdictions. However, several jurisdictions were grandfathered in at ratios other than $40 \%$.
} 
local government offered them at the start of our analysis period in 1970. The next two decades saw a rapid increase in the share of jurisdictions with some sort of age-based exemption; and, the percentage roughly doubled from 1990 to 2010.

Figure 1 depicts trends in our two treatment variables over time. The solid line shows the proportion of all people (not just those over 65) who live in a jurisdiction with some age-based property tax exemption. The proportion increases from 0.01 in 1970 to 0.59 in 2010. The dashed line shows the population-weighted average of our tax ratio treatment (i.e. the negative of the ratio of the average tax paid by somebody over 65 to somebody under 65). It increases from 0.001 (very close to the lower bound of 0) to 0.22. See Banzhaf, Mickey, and Patrick (2016) for additional discussion of these trends.

\subsection{Household Types and Housing values}

We analyze our outcomes at the county level due to the availability of Census data over time on household types and housing values. We use the 1970, 1980, 1990, and 2000 decennial Censuses as well as the 2008-2012 American Community Survey (ACS) data for $2010 .{ }^{10}$ For housing values, we use data from the National Historical Geographic Information System (NHGIS) by county, age, and tenure (Manson et al. 2017). Specifically, we use the decennial data on the aggregate value by age of householder and tenure by age of householder to calculate the mean value by age of householder.

Table 3 Panel B summarizes the sample counties' population, household types, and housing values across the years in our panel. Our sample counties reflect the general trend towards growth in the Sunbelt over the period, with the average county in our sample seeing consistent decadal increases in population and households. The average share of the population aged 65+ increases in the early periods but remains relatively stable over the later periods and peaks in 2010. Older households represent a larger share of owner-occupied housing units than population share throughout our sample, with their share rising until it peaks in 2000 and then falling slightly in 2010.

\footnotetext{
${ }^{10}$ The Census changed the universe over which some data were collected as well as the data points collected over the sample period. We used additional data whenever available to increase comparability over time.
} 
Perhaps most interesting, though, is the trend in mean housing values by age over the sample period. The mean value of homes occupied by older households is lower than the mean value of homes occupied by homeowners under 65 for most periods in the sample. This difference is consistent with the notion that older households locked into the smaller housing stock of earlier decades, or that they downsize after their children leave home. However, the gap between the mean value reported by older and young households is shrinking over time. By 2010, the average county in our sample has older homeowners occupying housing valued higher than their under 65 counterparts. This pattern suggests changes in the housing stock consumed by older households relative to younger households over time.

\section{Results}

\subsection{Analysis of Pre-trends}

One concern about our approach is the potential simultaneity between changes in demographic composition and policies regarding age-based tax exemptions. We address this potential concern in two ways. First, as noted above, one of our empirical strategies is to analyze the percentage change, over a decade, in the number of households or housing values, respectively, as a function of the lagged policy variables at the beginning of the decade. Given our time-invariant fixed effects and other controls, this means that identification comes from deviations in lagged policies from county patterns and state-wide temporal patterns. Similarly, given that the dependent variable is a percentage change, the county fixed effects imply we are controlling for county-specific time trends in the populations (resp. housing values), while specifications with county-age interactions control for age-specific trends. Our motivation for doing this is to minimize the potential for simultaneity, as policy shocks in, e.g., 1990 are less likely to be a function of future 1990-2000 population changes, especially after controlling for long-term trends.

Of course, it is not impossible that policy makers correctly forecast future changes and respond to them. For that reason, we additionally consider an analysis of parallel pre-trends in the data, using an event study design.

Analyzing pretrends in our context raises three issues. First, our quadruple difference design complicates the analysis. Just as a standard difference-in-difference does not depend on comparable levels in the pre-period, our quadruple difference does not depend on parallel trends in all four demographic categories. 
Second, we have a continuous treatment variable (lying on the unit interval), so strictly speaking we do not have "before" and "after" periods. For sake of the pre-trends analysis, we therefore create a new binary variant of our treatment variable, indicating whether a county had any age-based property tax exemption. ${ }^{11}$

Third, the timing of our treatment varies by county, so we must think of leads and lags in "event time." However, recent research has found that, when the timing of treatment varies among cross-sectional units, the coefficients on leads and lags are not interpretable in the way intuition would suggest (Athey and Imbens 2018; Borusyak and Jaravel 2017; Callaway and Sant'Anna 2018; Sun and Abraham 2020). In particular, Sun and Abraham (2020) establish that the relative period coefficients in such an event study are contaminated by effects from other relative periods, leading to potentially incorrect assessments of pre-trends in the presence of treatment effect heterogeneity and differential treatment timing.

Sun and Abraham (2020) nest a difference-in-differences design within the event-study framework and use regression methods to estimate an average treatment effect in each relative period. Their approach involves first estimating leads and lags in event time, but with separate coefficients for each "cohort," where in our context a cohort is a set of counties first treated in a particular year. Next, a weighted average of these effects is computed across cohorts. Sun and Abraham refer to their proposal as the "interaction-weighted" (IW) estimator.

We use the Sun and Abraham IW estimator to assess the validity of our empirical design, adapting it to our quadruple difference setting. In particular, we regress:

$$
\begin{aligned}
\ln y_{i j t}= & \gamma_{0}+\gamma_{1} 1(\text { Older })_{i}+\gamma_{2} 1(\text { Owner })_{i}+\gamma_{3}[1(\text { Owner }) \times 1(\text { Older })]_{i} \\
& +\sum_{i} \sum_{e \notin C} \sum_{l \neq-1} \varphi_{i, e, l}\left(1\left\{E_{j}=e\right\} \cdot D_{i j t}^{l}\right) \\
& +\eta_{i t}+\kappa_{i j}+\vartheta_{i j}+\varepsilon_{i j t}
\end{aligned}
$$

where $i$ is one of our four demographic groups, $j$ is a county, $e$ is a "cohort" as defined above, and $l$ is a lead or lag relative to time $t$. The term $1\left\{E_{j}=e\right\}$ indicates whether the time period of a

\footnotetext{
${ }^{11}$ We also considered alternative ways to map our original treatment variable into a binary variable, considering "cuts" on the unit interval at $0.2,0.4$, and 0.6 . Our results were not sensitive to these alternatives.
} 
county's initial treatment $E_{j}$ is equal to a particular year $e$ (i.e., whether it is in cohort $e$ ). The term $D_{i j t}^{l}$ is an indicator that an observation pertains to demographic group $i$ in county $j$ and $l$ periods relative to period $e$ when it was first treated (i.e. $t-E_{j}=l$ ). The summation over $l \neq-1$ implies that period $t=-1$ is omitted (the origin for event time); the summation over $e \notin C$ implies we are omitting the never-treated cohort.

Next, the weights $w_{e, l}$ for each $\varphi_{i, e, l}$ are estimated as the sample share of each cohort in each relative period $l$, for each demographic group. For example, in the four-decade lead, the cohort of counties first treated in 1990 will get zero weight, because those counties are never observed four decades before their treatment in our data (which begin in 1970). The IW estimator is a weighted average of the $\varphi_{i, e, l}$ terms from (1) given by:

$$
v_{i, l}=\sum_{e} \hat{\varphi}_{i, e, l} \operatorname{Pr}\left\{E_{j}=e \mid E_{j} \in[-l, T-l]\right\}
$$

where $\operatorname{Pr}\left\{E_{j}=e \mid E_{j} \in[-l, T-l]\right.$ is the probability that a county is first treated in the relevant window for observing its outcome relative time $l .{ }^{12}$

We then analyze the pretrends for our estimator using the quadruple difference $\left(v_{\text {older owner }, l}-v_{\text {older renter }, l}\right)-\left(v_{\text {younger owner }, l}-v_{\text {younger renter }, l}\right)$. Table 4 shows the event study coefficients for each of the four demographic groups, in a model of logged population as the dependent variable. The table compares estimates from the standard event-study approach using two-way fixed effects to the Sun-Abraham IW estimator. Standard errors are bootstrapped to account for variability in the first-stage estimates as well as the second-stage weights.

The quadruple difference (and confidence intervals) in event time are shown in Figure 2. The pre-period trend appears relatively flat, with leads being generally indistinguishable from either each other or zero except for possible small leads at period -2. This suggests that our estimation strategy does a relatively good job of eliminating concerns over pre-existing trends. Importantly, we also see a pronounced increase in the periods following treatment. We believe this

\footnotetext{
${ }^{12}$ See Sun and Abraham Eq. (20), p. 24. We have slightly simplified their notation here by dropping $g$, which allows for binning time periods together with a common coefficient. In our case, we have one coefficient for each lead or lag, so we can drop this generalization.
} 
analysis, along with our analysis of lagged effects, gives credence to our empirical approach.

\subsection{The Older Homeowner Effect}

Table 5 reports the results of from six separate regressions of the (log) number of households by type. Column (1) reports results for the specification in Equation (1), with Year X Owner and Year X Older effects replacing the basic owner and older effects. Column (2) further adds exemption-year and exemption-county fixed effects. Column (3) adds county-age, county-owner, and year-age-urban status fixed effects to the specification in Column (2). The latter variable controls for changes over time in age patterns by urban/rural counties. Panel A uses the housing unit weighted average of indicator variables denoting any age-based property tax exemption in the county and covered cities. Panel B uses one minus the ratio of under 65 to over 65 simulated property taxes as the measure of the age-based property tax exemption treatment.

Table 5 indicates a statistically significant effect in the quadruple difference from the policy, with an effect of about 0.45 log points when using the aggregation of policy indicator variables as the treatment and about 0.63 log points when using the simulated tax ratios. Overall in the data, the standard deviation of the latter measure of treatment is about half the former (0.14 vs. 0.29), so the effects of a one standard deviation are similar. The estimates are robust to specification. Although these coefficients may seem surprisingly large, interpreting these quadruple differences requires caution. These estimates do not imply population changes of this magnitude; they imply that the difference-in-differences effect of the exemptions for older owners differs from older renters by about 50\% more than the corresponding difference between younger owners and younger renters. Under slightly weaker identifying assumptions, we could identify these two effects separately. Then the effect on population by tenure (older vs. renter) for younger households can be read from the third row of the table. It shows a decrease of 0.11 to 0.53 log points. The relative increase on tenure for older households comes from the first row. Adding the two together would give the total effect on older households, which remains positive. Additionally, the magnitude of the estimates must be interpreted as a change from 0 to 1 in a variable which typically lies at the interior of the unit interval, again with standard deviations of 0.14 and 0.29 .

Table 6 shows the quadruple difference in the decadal population percentage changes from lagged treatments, where simultaneity is less of a concern. The effect is about a 2 percent change in Panel A of Table 6, and not statistically significant. In Panel B, using the simulated tax ratio, 
the effect is 69 percentage points, roughly equivalent to the $0.62 \log$ points from Table 5 .

\subsection{The Housing Consumption Effect}

Tables 7 and 8 present estimates of the change in counties' (log) mean housing values by age and percentage change in mean housing values by age, respectively. Column (1) reports results for the specification in Equation (2). Column (2) replaces the county and decade fixed effects in Equation (2) with exemption-year and exemption-county interactions. Column (3) adds countyage, year-age and year-urban status interactions to the specification in Column (2). (Note we no longer include year-age-urban, as we no longer have renters in the data, and little variation would remain when interacting age with year and a spatial variable.)

The results suggest that property tax exemption also increases housing consumption by older households, albeit the effect appears weaker than the combined effects on location choice and tenure. Table 7 Panel A Columns (1) and (2) report a 13 log-point increase in the mean house value reported by older households from an age-based property tax exemption for all eligible households in the county. This increase is net of the change in mean housing values for younger households in the treated counties and the change in untreated counties. Panel A Column (3) indicates a less precisely estimated increase of about 5 log points. Using the simulated tax ratio as our measure of treatment (Panel B) produces similar effects, ranging from 10 to 13 log points.

Table 8 reveals a similar pattern for our estimates of the percent change in counties' mean housing values by age, with mean housing values increasing by approximately 8 percent using the housing unit weighted indicator of treatment in Panel A Columns 1 and 2 and 41 percent using the simulated treatment measure in Panel B Columns 4 and 5. Columns 3 and 6 indicate a decrease in the percent change when we add additional controls for decade-by-age and decade-by-urban effects, although these estimates are less precisely estimated.

The results in Tables 7 and 8 generally suggest that the reductions in the user cost of housing conferred by age-based property tax exemptions effect older households' decision on the intensive margin as well as the extensive margin.

\subsection{The Sorting Model}

Table 9a shows the estimated parameters of the sorting model described in equation (3). It shows all coefficients for the policy are of the expected sign and statistically significant, including 
the main treatment variable for older households when choosing owner-occupied units. It shows younger households also are attracted to owning in counties with the policy, which makes sense if they are forward looking or if they are attracted to counties with age cutoffs below 65 . However, the parameters are in utils, which are hard to interpret in isolation.

Accordingly, Table 9b simulates a counterfactual scenario in which Cobb County had not introduced their generous policy of $100 \%$ tax exemptions on school taxes and had instead treated older households on par with younger ones. The first two columns use the utility parameters from Model A in Table 9a, the last two use Model B. Although we do not know the supply elasticity, nor have we estimated the price elasticies of demand, we can still bound the population changes. At one bookend, we can assume perfectly elastic supply, so there are no price changes. Under this assumption, the equilibrium population effects are equal to the shifts in demand. At the other bookend, we can assume perfectly inelastic housing supply and assume the price elasticities are the same for all households; then relative population proportions among types and tenure status would be the same as the perfectly elastic case, but total population would be constant.

We predict large decreases in the population of older owners, from 7,600 to 11,700 households depending on the model, or 31\% to 54\%. In most models, young owners decline as well (although the effect depends on the assumed elasticity of housing supply), whereas renters increase slightly, with bigger increases under the assumption of more inelastic supply. However, to put these changes in perspective, the results suggest more modest changes as a percent of overall number of households in the county. For example, in the first column, the predicted decline in older owners represents 3.2\% of the county's households. Because we are assuming an inelastic supply of housing in this model, these losses are exactly offset by gains, with an increase in young renters equal to $2.2 \%$ of the county's households, an increase in young owners of $0.8 \%$ and an increase in older renters of $0.2 \%$. Because they are derived from an equilibrium model, these should be interpreted as long run ( 10 year) responses.

Interestingly, Table 9b shows surprisingly large increases in young renters if we assume perfectly inelastic supply (6.5\% and $22.1 \%$ for Models A and B respectively), but much more modest effects if we assume perfectly elastic supply ( $0.2 \%$ and $1.4 \%$ respectively). On the other hand, we find larger decreases in the population of young owners with perfectly elastic supply. One plausible explanation of this pattern is that senior property tax exemptions do not directly 
affect young renters but do affect young owners. ${ }^{13}$ Then, in the model with perfectly elastic supply, where equilibrium quantities respond 1:1 with the shift in demands, we find a big decrease in young owners as they flee the jurisdiction, but no change in young renters, who are indifferent. But in the model with perfectly inelastic supply, equilibrium requires some group to fill the vacancies left behind, with price adjustments offering the needed incentive. This simultaneously tamps down the flight of young owners but also induces, in equilibrium, young renters into the jurisdiction. In short, the model with perfectly elastic supply reveals the demand-side effects for each group independently of the others, while the model with perfectly inelastic supply shows relative effects with $100 \%$ crowding out.

Using these results, we can compute a back-of-the-envelope estimate of the fiscal impact of Cobb County's tax exemptions, if we assume the marginal household affected by the policy has the average property tax assessment of its age group. ${ }^{14}$ Based on Models A with inelastic supply, Cobb's age-based tax exemption costs the county $\$ 56.2 \mathrm{~m}$ annually (or $12 \%$ of the school district's local tax revenue and 6\% of its budget in Fiscal Year 2010). Using Model B, the estimate is $\$ 59.0 \mathrm{~m}$. In addition to assuming the number of households is fixed, both these estimates assume housing units do not change size or quality. Assuming the opposite extreme of inelastic supply of housing units and a putty-clay model of the housing stock, the estimate is much lower, at a cost of \$33.1m annually using Model A and a gain of \$19.3m using Model B. Because with perfectly elastic supply the increased demand of older owners does not crowd out any other groups, the direct cost of not taxing their homes can be offset by the overall gain in population, which in Model B involves a substantial number of younger owners. This result highlights the theoretical possibility of a Laffer Curve effect when elasticities are high. In this case we have not only imposed perfectly elastic supply, we have also considered a change in the tax policy of a single local

\footnotetext{
${ }^{13}$ For example, perhaps property taxes are increased on the rest of the owner-occupied housing stock (thus affecting young owners) but are not passed on to renters. Alternatively, perhaps property taxes are held constant on other groups but school expenditures decline, and young owners are more likely to have families in public schools than young renters.

${ }^{14}$ We obtained the average property tax assessment for households over 62 directly from the Cobb County tax assessor. For younger households, we take the average market value in Cobb reported in the ACS for households under 65, and "calibrate" it by the ratio of the average tax assessment for older owners to the corresponding value for older owners in the ACS. We also assume the millage rate is fixed and that, absent the age-based exemption, older owners would take the \$10,000 exemption available to other owner-occupied housing. In Cobb, rental units get no exemptions and pay the same millage rate.
} 
jurisdiction, for which demand elasticities are presumably high. We would not expect such a large effect for a state-wide tax policy, for instance. We also caution that this analysis does not consider the cost of supplying additional public services to the new residents.

\section{Conclusions}

Age-based property tax exemptions are likely to continue to be an important and controversial policy tool in the current environment of increasing property values, shifting property tax burdens towards residential property, declining property tax bases, and increased pressure for decentralized provision of public goods. Such exemptions have the potential to provide welfare-enhancements as well as to exacerbate public good financing crises. The consequences of age-based property tax exemptions depend upon the extent to which they influence households' location decisions, housing tenure decisions, and housing consumption.

We provide the first evidence on (long-term) changes in household composition and housing consumption attributable to local, age-based property tax exemptions. We find significant increases in older homeowners and in the growth rate of older homeowners from age-based property tax exemptions. Our results suggest that the combined effects of age-based property tax exemption induced migration and housing tenure changes are substantial, with a 32-54 percent increase in the number of older homeowners from adopting an age-based property tax exemptions. We also provide evidence that age-based property tax exemptions increase housing consumption among older households. 


\section{References}

Athey, Susan and Guido Imbens. 2018. "Design-based Analysis in Difference-In-Differences Settings with Staggered Adoption," NBER Working Paper 24963.

Augustine, Nancy Y., Michael E. Bell, David Brunori, and Joan M. Youngman. 2009. "The Property Tax Under Siege," in Erosion of the Property Tax Base: Trends, Causes, and Consequences, ed. by Nancy Y. Augustine, Michael E. Bell, David Brunori, and Joan M. Youngman. Cambridge, Massachusetts: Lincoln Institute of Land Policy.

Banzhaf, H. Spencer, Ryan Mickey, and Carlianne E. Patrick. 2016. "Age-Based Property Tax Exemptions in Georgia," State Tax Notes, Sept. 26, 2016, pp.1055-60.

Banzhaf, H. Spencer, and Wallace E. Oates. 2013. "On Fiscal Illusion in Local Public Finance: Re-Examining Ricardian Equivalence and the Renter Effect." National Tax Journal 66(3): 511-40.

Baer, David. 1998. "Awareness and Popularity of Property Tax Relief Programs." AARP Public Policy Institute.

Borusyak, Kirill and Xavier Jaravel. 2017. "Revisiting Event Study Designs," working paper, SSRN: https://ssrn.com/astract=2826228 or http://dx.doi.org/10.2139/ssrn.2826228.

Callaway, Brantly and Pedro H. C. Sant'Anna. 2018. "Difference-in-Differences with Multiple Time Periods and an Application on the Minimum Wage and Employment," working paper, http://dx.doi.org/10.2139/ssrn.3148250.

Conway, Karen Smith, and Jonathan C. Rork. 2006. "State 'Death' Taxes and Elderly Migration: The Chicken or the Egg?" National Tax Journal 59(1): 97-128.

Conway, Karen Smith, and Jonathan C. Rork. 2012. "No Country for Old Men (or Women): Do State Tax Policies Drive away the Elderly?" National Tax Journal 65(2): 313-56.

Davis, Janel. 2010. "Tax Breaks for Seniors: Can Counties Afford Them?" Atlanta Journal-Constitution.

Downey, Maureen. 2013. "Make 62-Year-Olds Pay School Taxes," Atlanta Journal-Constitution, May 21.

Farnham, Martin, and Purvi Sevak. 2006. "State Fiscal Institutions and Empty-Nest Migration: Are Tiebout Voters Hobbled?" Journal of Public Economics 90 (3): 407-27.

Gallagher, Ryan M., Joseph J. Persky, and Haydar Kurban. 2018. "The Growth of Local Education Transfers: Explaining How Older Households Have Supported Schools." Public Finance Review 46(6): 1002-23.

Hanson, Andrew. 2012. "Size of home, homeownership, and the mortgage interest deduction." Journal of Housing Economics 21(3): 195-210. 
Langley, Adam H. 2015. "Estimating Tax Savings from Homestead Exemptions and Property Tax Credits." Working Paper. Cambridge, MA: Lincoln Institute of Land Policy.

Lincoln Institute of Land Policy and George Washington Institute of Public Policy. 2020. Significant Features of the Property Tax. https://www.lincolninst.edu/research-data/datatoolkits/significant-features-property-tax/access-property-tax-database/residential-property-tax-relief-programs. Accessed July 7th.

MacKay, Robert C. 2014. "Implicit Debt Capitalization in Local Housing Prices: An Example Of Unfunded Pension Liabilities." National Tax Journal 67(1): 77-112.

Manson, Steven, Jonathan Schroeder, David Van Riper, and Steven Ruggles. 2017. IPUMS National Historical Geographic Information System: Version 12.0. Minneapolis: University of Minnesota. http://doi.org/10.18128/D050.V12.0

Moulton, Jeremy G., Bennie D. Waller, and Scott A. Wentland. 2018. "Who Benefits from Targeted Property Tax Relief? Evidence from Virginia Elections." Journal of Policy Analysis and Management 37: 240-64.

Moretti, Enrico, and Daniel J. Wilson. 2020. "Taxing Billionaires: Estate Taxes and the Geographical Location of the Ultra-Wealthy." NBER Working Paper 26387.

Oates, Wallace E. 1969. "The Effects of Property Taxes and Local Public Spending on Property Values: An Empirical Study of Tax Capitalization and the Tiebout hypothesis." Journal of Political Economy 77(6: 957-71.

Önder, Ali Sina, and Herwig J. Schlunk. 2019. "State Taxes, Tax Exemptions and Elderly Migration." Journal of Regional Analysis and Policy 45(1): 47-67.

Palmon, Oded, and Barton A. Smith. 1998. "New Evidence on Property Tax Capitalization." Journal of Political Economy 106(5): 1099-111.

Seslen, Tracey. 2005. "Property Tax Abatement Programs: Does Relief Really Keep Grandma in Her Home." MIT Dissertation.

Shan, Hui. 2010. "Property Taxes and Elderly Mobility." Journal of Urban Economics 67:194205.

Stadelmann, David, and Reiner Eichenberger. 2014. "Public Debts Capitalize into Property Prices: Empirical Evidence for a New Perspective on Debt Incidence." International Tax and Public Finance 21(3): 498-529.

Sun, Liyang, and Sarah Abraham. 2020. "Estimating Dynamic Treatment Effects in Event Studies with Heterogeneous Treatment Effects." Mimeo. https://arxiv.org/abs/1804.05785 
Table 1: Summary of Identification Strategy for the Homeowner Effect

\begin{tabular}{|l|c|c|c|}
\hline & Renter & Owner & $\begin{array}{c}\text { Difference } \\
\text { (Owner-Renter) }\end{array}$ \\
\hline Young & $\gamma_{4}$ & $\gamma_{4}+\gamma_{6}$ & $\gamma_{6}$ \\
\hline Older & $\gamma_{4}+\gamma_{5}$ & $\gamma_{4}+\gamma_{5}+\gamma_{6}+\gamma_{7}$ & $\gamma_{6}+\gamma_{7}$ \\
\hline $\begin{array}{l}\text { Difference } \\
\text { (Older-Young) }\end{array}$ & $\gamma_{5}$ & $\gamma_{5}+\gamma_{7}$ & $\gamma_{7}$ \\
\hline
\end{tabular}

The four upper left cells represent four jurisdiction-year difference-in-differences for the four demographic categories shown (young renters, young owners, older renters, and older owners). The bottom rows for the first two columns and right-most column for the first rows represent triple differences. The lower-right corner represents the quadruple difference. 
Table 2. Percent of jurisdictions with age-specific property exemptions, by jurisdiction type and year

\begin{tabular}{lccccc}
\hline \hline Jurisdiction Type & $\mathbf{1 9 7 0}$ & $\mathbf{1 9 8 0}$ & $\mathbf{1 9 9 0}$ & $\mathbf{2 0 0 0}$ & $\mathbf{2 0 1 0}$ \\
\hline Counties & 0.0 & 3.1 & 19.5 & 35.9 & 41.5 \\
$\begin{array}{l}\text { County } \\
\text { School Districts }\end{array}$ & 0.6 & 6.3 & 33.3 & 46.5 & 54.7 \\
$\begin{array}{l}\text { Cities } \\
\text { City }\end{array}$ & 3.6 & 15.7 & 19.6 & 31.3 & 36.9 \\
School Districts & 3.9 & 19.2 & 37.0 & 53.9 & 61.5 \\
\hline \hline
\end{tabular}


Table 3. County Summary Statistics

\begin{tabular}{lccccc}
\hline \hline & 1970 & 1980 & 1990 & 2000 & 2010 \\
\hline Weighted Indicator & 0.0048 & 0.0275 & 0.155 & 0.241 & 0.369 \\
& $(0.0470)$ & $(0.113)$ & $(0.247)$ & $(0.309)$ & $(0.396)$ \\
Simulated Taxes under 65 & 136.6 & 422.1 & 902.2 & 1488.7 & 1979.0 \\
& $(14.80)$ & $(50.48)$ & $(106.2)$ & $(175.4)$ & $(251.6)$ \\
Simulated Taxes over 65 & 136.4 & 350.2 & 803.7 & 1228.6 & 1560.4 \\
& $(14.60)$ & $(46.18)$ & $(153.1)$ & $(255.8)$ & $(469.2)$ \\
Simulated Tax Ratio & 0.001 & 0.169 & 0.113 & 0.179 & 0.216 \\
& $(0.0149)$ & $(0.0605)$ & $(0.118)$ & $(0.124)$ & $(0.197)$ \\
\hline Total population & & & Panel B & & \\
Share of Pop. 65+ & 27988.6 & 34359.2 & 40743.5 & 51487.1 & 73903.2 \\
& $(63333.0)$ & $(69744.4)$ & $(83663.8)$ & $(108931.2)$ & $(139963.8)$ \\
Owner occupied units & 0.0967 & 0.114 & 0.125 & 0.120 & 0.130 \\
& $(0.0227)$ & $(0.0281)$ & $(0.0331)$ & $(0.0336)$ & $(0.0303)$ \\
Owner occupied by 65+ & 4529 & 7650.5 & 9665.2 & 10180.6 & 17591.9 \\
& $(9543.2)$ & $(14040.9)$ & $(18268.0)$ & $(20897.2)$ & $(31989.4)$ \\
& 608.3 & 1543.6 & 2035.9 & 2582.3 & 3914.5 \\
Renter occupied units & $(1120.3)$ & $(2509.9)$ & $(3301.9)$ & $(4136.8)$ & $(5694.6)$ \\
& 2435.8 & 4120.9 & 5219.2 & 5500.4 & 9156.4 \\
Renter occupied by 65+ & $(6511.8)$ & $(11913.4)$ & $(14220.0)$ & $(15356.1)$ & $(20805.7)$ \\
Mean value under 65 & 231.8 & 640.7 & 620.6 & 644.8 & 887.1 \\
& $(519.5)$ & $(1664.9)$ & $(1523.5)$ & $(1525.1)$ & $(1824.8)$ \\
& $12,877.3$ & $35,090.8$ & $62,222.9$ & $103,554.2$ & $151,718.3$ \\
& $(2770.2)$ & $(8360.1)$ & $(20094.7)$ & $(36960.5)$ & $(52742.1)$ \\
& $10,740.0$ & $26,178.0$ & $51,780.1$ & $89,296.9$ & $154,005.9$ \\
& $(2248.7)$ & $(6021.2)$ & $(16963.9)$ & $(34515.8)$ & $(62374.4)$ \\
\hline \hline
\end{tabular}

NOTES: The table reports the mean and standard deviation of household composition and housing values as well as our measure of treatment in the sample of 159 Georgia counties over time. 
Table 4: Comparing Relative Period Estimates by Household Type

\begin{tabular}{|c|c|c|c|c|c|c|c|c|}
\hline \multirow[t]{2}{*}{$\begin{array}{l}\text { Relative } \\
\text { Period }\end{array}$} & \multicolumn{2}{|c|}{ Older Owner } & \multicolumn{2}{|c|}{ Older Renter } & \multicolumn{2}{|c|}{ Younger Owner } & \multicolumn{2}{|c|}{ Younger Renter } \\
\hline & $\begin{array}{l}\text { 2-way } \\
\text { FE }\end{array}$ & IW & $\begin{array}{l}\text { 2-way } \\
\text { FE }\end{array}$ & IW & $\begin{array}{l}\text { 2-way } \\
\text { FE }\end{array}$ & IW & $\begin{array}{l}\text { 2-way } \\
\text { FE }\end{array}$ & IW \\
\hline \multirow[t]{2}{*}{-4} & -0.13000 & -0.06258 & 0.03686 & 0.02392 & -0.02737 & 0.00210 & -0.03265 & -0.08353 \\
\hline & (0.1339) & $(0.1400)$ & $(0.3182)$ & $(0.3491)$ & $(0.1507)$ & $(0.2043)$ & $(0.1933)$ & $(0.2353)$ \\
\hline \multirow[t]{2}{*}{-3} & -0.18971 & -0.15686 & -0.04993 & -0.10403 & -0.08840 & -0.08923 & -0.19929 & -0.28707 \\
\hline & $(0.0975)$ & $(0.0783)$ & $(0.1474)$ & $(0.1440)$ & $(0.1314)$ & $(0.1137)$ & $(0.1300)$ & (0.1183) \\
\hline \multirow[t]{2}{*}{-2} & -0.16451 & -0.14531 & -0.04721 & -0.07160 & -0.07669 & -0.05682 & -0.15596 & -0.19017 \\
\hline & $(0.0451)$ & $(0.0394)$ & $(0.0721)$ & $(0.0621)$ & $(0.0581)$ & $(0.0475)$ & $(0.0644)$ & $(0.0550)$ \\
\hline-1 & 0 & 0 & 0 & 0 & 0 & 0 & 0 & 0 \\
\hline \multirow[t]{2}{*}{0} & 0.13974 & 0.13261 & 0.15838 & 0.16086 & 0.10486 & 0.10740 & 0.22051 & 0.23265 \\
\hline & $(0.0427)$ & $(0.0437)$ & $(0.0612)$ & $(0.0615)$ & $(0.0560)$ & $(0.0560)$ & $(0.0601)$ & $(0.0621)$ \\
\hline \multirow[t]{2}{*}{1} & 0.35741 & 0.34216 & 0.34494 & 0.32593 & 0.19010 & 0.19773 & 0.43137 & 0.43525 \\
\hline & $(0.0775)$ & $(0.0773)$ & $(0.1010)$ & $(0.1024)$ & $(0.1015)$ & $(0.1036)$ & $(0.1019)$ & $(0.1062)$ \\
\hline \multirow[t]{2}{*}{2} & 0.54607 & 0.53885 & 0.50097 & 0.48195 & 0.22676 & 0.21968 & 0.56479 & 0.54592 \\
\hline & $(0.1305)$ & $(0.1345)$ & $(0.1499)$ & $(0.1557)$ & $(0.1425)$ & $(0.1392)$ & $(0.1511)$ & $(0.1514)$ \\
\hline \multirow[t]{2}{*}{3} & 0.52968 & 0.42063 & 0.51885 & 0.55130 & 0.18344 & 0.02526 & 0.54830 & 0.53161 \\
\hline & $(0.1570)$ & $(0.1747)$ & $(0.2342)$ & $(0.2294)$ & $(0.2212)$ & $(0.2948)$ & $(0.2407)$ & $(0.2953)$ \\
\hline
\end{tabular}

Note: Clustered bootstrap standard errors 
Table 5. Count of household type quadruple-difference

\begin{tabular}{|c|c|c|c|c|c|c|}
\hline \multirow[b]{2}{*}{$\gamma_{7}:$ Quadruple Difference } & \multicolumn{3}{|c|}{ Panel A: Exemption Indicator } & \multicolumn{3}{|c|}{ Panel B: Simulated Tax Ratio } \\
\hline & $\begin{array}{c}(1) \\
0.447 * * * \\
(0.0666)\end{array}$ & $\begin{array}{c}(2) \\
0.447 * * * \\
(0.0705)\end{array}$ & $\begin{array}{c}(3) \\
0.447 * * * \\
(0.0718)\end{array}$ & $\begin{array}{c}(1) \\
0.625^{* * *} \\
(0.118)\end{array}$ & $\begin{array}{c}(2) \\
0.625^{* * *} \\
(0.125)\end{array}$ & $\begin{array}{c}(3) \\
0.625^{* * *} \\
(0.129)\end{array}$ \\
\hline Triple Differences & & & & & & \\
\hline $\begin{array}{l}\gamma_{5}+\gamma_{7}: \text { Older Owner - } \\
\text { Younger Owner }\end{array}$ & $\begin{array}{c}-0.290 * * * \\
(0.081)\end{array}$ & $\begin{array}{c}0.235^{* * *} \\
(0.057)\end{array}$ & $\begin{array}{c}0.235 * * * \\
(0.058)\end{array}$ & $\begin{array}{c}-0.801^{* * *} \\
(0.183)\end{array}$ & $\begin{array}{c}0.213 \\
(0.131)\end{array}$ & $\begin{array}{c}0.213 \\
(0.135)\end{array}$ \\
\hline $\begin{array}{l}\gamma_{6}+\gamma_{7}: \text { Older Owner - } \\
\text { Older Renter }\end{array}$ & $\begin{array}{c}0.273^{* * *} \\
(0.064)\end{array}$ & $\begin{array}{c}0.103^{* * *} \\
(0.060)\end{array}$ & $\begin{array}{c}0.103^{* * *} \\
(0.061)\end{array}$ & $\begin{array}{c}0.511^{* * * *} \\
(0.134)\end{array}$ & $\begin{array}{c}0.102 \\
(0.115)\end{array}$ & $\begin{array}{c}0.102 \\
(0.119)\end{array}$ \\
\hline $\begin{array}{l}\gamma_{5}: \text { Older Renter - } \\
\text { Younger Renter }\end{array}$ & $\begin{array}{c}-0.737^{* * *} \\
(0.103)\end{array}$ & $\begin{array}{c}-0.212^{* * *} \\
(0.0566)\end{array}$ & $\begin{array}{c}-0.212 * * * \\
(0.0576)\end{array}$ & $\begin{array}{c}-1.426^{* * *} \\
(0.187)\end{array}$ & $\begin{array}{c}-0.412^{* * *} \\
(0.111)\end{array}$ & $\begin{array}{c}-0.412^{* * *} \\
(0.114)\end{array}$ \\
\hline $\begin{array}{l}\gamma_{6}: \text { Younger Owner - } \\
\text { Younger Renter }\end{array}$ & $\begin{array}{l}-0.174 * \\
(0.0949)\end{array}$ & $\begin{array}{c}-0.344 * * * \\
(0.0644)\end{array}$ & $\begin{array}{c}-0.344^{* * * *} \\
(0.0656)\end{array}$ & $\begin{array}{l}-0.113 \\
(0.200)\end{array}$ & $\begin{array}{c}-0.523 * * * \\
(0.135)\end{array}$ & $\begin{array}{c}-0.523^{* * * *} \\
(0.139)\end{array}$ \\
\hline $\begin{array}{l}\gamma_{4}: \text { DD for } \\
\text { Young Renters }\end{array}$ & $\begin{array}{c}0.836 * * * \\
(0.101)\end{array}$ & $\begin{array}{l}0.540^{* * *} \\
(0.0826)\end{array}$ & N/A & $\begin{array}{c}1.513^{* * * *} \\
(0.211)\end{array}$ & $\begin{array}{c}0.971^{* * * *} \\
(0.169)\end{array}$ & N/A \\
\hline Year FE & $\mathrm{Y}$ & $\mathrm{Y}$ & $\mathrm{Y}$ & $\mathrm{Y}$ & $\mathrm{Y}$ & $\mathrm{Y}$ \\
\hline Year X Owner FE & $\mathrm{Y}$ & Y & $\mathrm{Y}$ & Y & Y & Y \\
\hline Year X Older FE & $\mathrm{Y}$ & Y & $\mathrm{Y}$ & Y & Y & $\mathrm{Y}$ \\
\hline County & $\mathrm{Y}$ & $\mathrm{Y}$ & $\mathrm{Y}$ & $\mathrm{Y}$ & $\mathrm{Y}$ & Y \\
\hline Coun & $\mathrm{N}$ & $\mathrm{Y}$ & $\mathrm{Y}$ & $\mathrm{N}$ & $\mathrm{Y}$ & $\mathrm{Y}$ \\
\hline County X Owner FE & $\mathrm{N}$ & $\mathrm{Y}$ & $\mathrm{Y}$ & $\mathrm{N}$ & $\mathrm{Y}$ & $\mathrm{Y}$ \\
\hline Year X Older X Urban & $\mathrm{N}$ & $\mathrm{Y}$ & $\mathrm{Y}$ & $\mathrm{N}$ & $\mathrm{Y}$ & $\mathrm{Y}$ \\
\hline & $\mathrm{N}$ & $\mathrm{N}$ & $\mathrm{Y}$ & $\mathrm{N}$ & $\mathrm{N}$ & $\mathrm{Y}$ \\
\hline Treatment X County & $\mathrm{N}$ & $\mathrm{N}$ & $\mathrm{Y}$ & $\mathrm{N}$ & $\mathrm{N}$ & $\mathrm{Y}$ \\
\hline Observations & 3,180 & 3,180 & 3,180 & 3,176 & 3,176 & 3,176 \\
\hline R-squared & 0.947 & 0.974 & 0.981 & 0.946 & 0.973 & 0.979 \\
\hline
\end{tabular}

NOTES: The table presents results from six separate regressions of the (log) number of each household type. Column (1) reports results for Equation (1), with year X owner and year $\mathrm{X}$ older effects replacing owner and older effects. Column (2) adds county-age, county-owner, and year-age-urban status interactions to the specification in Column (2). Column (3) replaces the county and decade fixed effects in Equation (1) with exemption-year and exemption-county interactions. Panel A uses the housing unit weighted average of indicator variables denoting any age-based property tax exemption in the county and covered cities. Panel B uses the inverse of the ratio of under 65 to over 65 simulated property taxes as the measure of the age-based property tax exemption treatment.

Robust standard errors clustered at the county level are reported in parentheses.

${ }^{* * *} \mathrm{p}<0.01,{ }^{* *} \mathrm{p}<0.05,{ }^{*} \mathrm{p}<0.1$ 
Table 6. Percentage change in household type quadruple-difference

\begin{tabular}{|c|c|c|c|c|c|c|}
\hline \multirow[b]{2}{*}{$\gamma_{7}:$ Quadruple Difference } & \multicolumn{3}{|c|}{ Panel A: Exemption Indicator } & \multicolumn{3}{|c|}{ Panel B: Simulated Tax Ratio } \\
\hline & $\begin{array}{c}(1) \\
0.0186 \\
(0.049)\end{array}$ & $\begin{array}{c}(2) \\
0.0186 \\
(0.050)\end{array}$ & $\begin{array}{c}(3) \\
0.0186 \\
(0.054)\end{array}$ & $\begin{array}{c}(1) \\
0.691^{* * *} \\
(0.135)\end{array}$ & $\begin{array}{c}(2) \\
0.691^{* * *} \\
(0.145)\end{array}$ & $\begin{array}{c}(3) \\
0.691 * * * \\
(0.152)\end{array}$ \\
\hline \multicolumn{7}{|l|}{ Triple Differences } \\
\hline $\begin{array}{l}\gamma_{5}+\gamma_{7}: \text { Older Owner - } \\
\text { Younger Owner }\end{array}$ & $\begin{array}{c}0.1592 * * * \\
(0.034)\end{array}$ & $\begin{array}{c}0.1791^{* * *} \\
(0.064)\end{array}$ & $\begin{array}{c}0.1791 * * * \\
(0.065)\end{array}$ & $\begin{array}{c}0.5941^{* * * *} \\
(0.103)\end{array}$ & $\begin{array}{c}0.7145^{* * *} \\
(0.160)\end{array}$ & $\begin{array}{c}0.7145^{* * * *} \\
(0.167)\end{array}$ \\
\hline $\begin{array}{l}\gamma_{6}+\gamma_{7}: \text { Older Owner - } \\
\text { Older Renter }\end{array}$ & $\begin{array}{c}-0.0084 \\
(0.040)\end{array}$ & $\begin{array}{l}0.1523^{* * *} \\
(0.056)\end{array}$ & $\begin{array}{c}0.1523^{* * *} \\
(0.058)\end{array}$ & $\begin{array}{c}0.3577^{* * *} \\
(0.089)\end{array}$ & $\begin{array}{c}0.6903^{* * *} \\
(0.130)\end{array}$ & $\begin{array}{c}0.6903^{* * *} \\
(0.135)\end{array}$ \\
\hline $\begin{array}{l}\gamma_{5}: \text { Older Renter - } \\
\text { Younger Renter }\end{array}$ & $\begin{array}{c}0.141^{* * *} \\
(0.049)\end{array}$ & $\begin{array}{c}0.161^{* *} \\
(0.076)\end{array}$ & $\begin{array}{l}0.161^{* *} \\
(0.078)\end{array}$ & $\begin{array}{c}-0.0974 \\
(0.096)\end{array}$ & $\begin{array}{l}0.0231 \\
(0.141)\end{array}$ & $\begin{array}{l}0.0231 \\
(0.146)\end{array}$ \\
\hline $\begin{array}{l}\gamma_{6}: \text { Younger Owner - } \\
\text { Younger Renter }\end{array}$ & $\begin{array}{l}-0.0270 \\
(0.033)\end{array}$ & $\begin{array}{c}0.134^{* *} \\
(0.062)\end{array}$ & $\begin{array}{l}0.134^{* *} \\
(0.064)\end{array}$ & $\begin{array}{c}-0.334^{* * *} \\
(0.087)\end{array}$ & $\begin{array}{c}-0.00108 \\
(0.160)\end{array}$ & $\begin{array}{c}-0.00108 \\
(0.167)\end{array}$ \\
\hline $\begin{array}{l}\gamma_{4}: \text { DD for } \\
\text { Young Renters }\end{array}$ & $\begin{array}{c}-0.122 * * \\
(0.048)\end{array}$ & $\begin{array}{c}-0.182 * * * \\
(0.066)\end{array}$ & N/A & $\begin{array}{l}-0.0549 \\
(0.128)\end{array}$ & $\begin{array}{l}-0.209 \\
(0.144)\end{array}$ & N/A \\
\hline Year FE & $\mathrm{Y}$ & $\mathrm{Y}$ & $\mathrm{Y}$ & $\mathrm{Y}$ & Y & $\mathrm{Y}$ \\
\hline Year X Owner FE & Y & $\mathrm{Y}$ & $\mathrm{Y}$ & $\mathrm{Y}$ & $\mathrm{Y}$ & $\mathrm{Y}$ \\
\hline Year X Older FE & $\mathrm{Y}$ & $\mathrm{Y}$ & $\mathrm{Y}$ & $\mathrm{Y}$ & $\mathrm{Y}$ & $\mathrm{Y}$ \\
\hline County FE & $\mathrm{Y}$ & $\mathrm{Y}$ & $\mathrm{Y}$ & $\mathrm{Y}$ & $\mathrm{Y}$ & $\mathrm{Y}$ \\
\hline County X Older FE & $\mathrm{N}$ & $\mathrm{Y}$ & $\mathrm{Y}$ & $\mathrm{N}$ & $\mathrm{Y}$ & $\mathrm{Y}$ \\
\hline County X Owner FE & $\mathrm{N}$ & $\mathrm{Y}$ & $\mathrm{Y}$ & $\mathrm{N}$ & Y & $\mathrm{Y}$ \\
\hline Year X Older X Urban & $\mathrm{N}$ & $\mathrm{Y}$ & $\mathrm{Y}$ & $\mathrm{N}$ & $\mathrm{Y}$ & $\mathrm{Y}$ \\
\hline Treatment X Year & $\mathrm{N}$ & $\mathrm{N}$ & $\mathrm{Y}$ & $\mathrm{N}$ & $\mathrm{N}$ & $\mathrm{Y}$ \\
\hline Treatment X County & $\mathrm{N}$ & $\mathrm{N}$ & $\mathrm{Y}$ & $\mathrm{N}$ & $\mathrm{N}$ & $\mathrm{Y}$ \\
\hline Observations & 2,544 & 2,544 & 2,544 & 2,540 & 2,540 & 2,540 \\
\hline R-squared & 0.719 & 0.751 & 0.768 & 0.721 & 0.754 & 0.779 \\
\hline
\end{tabular}

NOTES: The table presents results from six separate regressions of the decadal percentage change in the population of each household type (using the midpoint formula in the denominator) on the policy values at the beginning of the decade. Column (1) reports results for Equation (1). Column (2) adds county-age, county-owner, and year-age-urban status interactions to the specification in Column (2). Column (3) replaces the county and decade fixed effects in Equation (1) with exemption-year and exemption-county interactions. Panel A uses the housing unit weighted average of indicator variables denoting any age-based property tax exemption in the county and covered cities. Panel B uses the inverse ratio of under 65 to over 65 simulated property taxes as the measure of the age-based property tax exemption treatment.

Robust standard errors clustered at the county level are reported in parentheses.

*** $\mathrm{p}<0.01,{ }^{* *} \mathrm{p}<0.05,{ }^{*} \mathrm{p}<0.1$ 
Table 7. Mean housing value triple-difference

\begin{tabular}{|c|c|c|c|c|c|c|}
\hline & \multicolumn{3}{|c|}{ Panel A: Exemption Indicator } & \multicolumn{3}{|c|}{ Panel B: Simulated Tax Ratio } \\
\hline & (1) & (2) & (3) & (1) & (2) & (3) \\
\hline$\pi_{3}$ : Treatment X Older & $0.128 * * *$ & $0.0529 *$ & $0.0529 *$ & $0.106^{* * *}$ & $0.127^{* *}$ & $0.127 *$ \\
\hline & $(0.0220)$ & $(0.0288)$ & $(0.0300)$ & $(0.0405)$ & $(0.0618)$ & $(0.0665)$ \\
\hline$\pi_{2}$ : Treatment & $\begin{array}{c}0.0639 * \\
(0.0384)\end{array}$ & $\begin{array}{c}0.0855^{* *} \\
(0.0399)\end{array}$ & N/A & $\begin{array}{c}0.202^{* *} \\
(0.0897)\end{array}$ & $\begin{array}{c}0.146 \\
(0.0887)\end{array}$ & N/A \\
\hline$\pi_{1}$ : Older & $\mathrm{Y}$ & $\mathrm{Y}$ & Y & $\mathrm{Y}$ & $\mathrm{Y}$ & Y \\
\hline County FE & Y & $\mathrm{Y}$ & $\mathrm{Y}$ & $\mathrm{Y}$ & $\mathrm{Y}$ & $\mathrm{Y}$ \\
\hline Year FE & $\mathrm{Y}$ & $\mathrm{Y}$ & $\mathrm{Y}$ & $\mathrm{Y}$ & $\mathrm{Y}$ & $\mathrm{Y}$ \\
\hline County X Older & $\mathrm{N}$ & $\mathrm{Y}$ & $\mathrm{Y}$ & $\mathrm{N}$ & $\mathrm{Y}$ & $\mathrm{Y}$ \\
\hline Year X Urban & $\mathrm{N}$ & $\mathrm{Y}$ & $\mathrm{Y}$ & $\mathrm{N}$ & $\mathrm{Y}$ & $\mathrm{Y}$ \\
\hline Year X Older & $\mathrm{N}$ & $\mathrm{Y}$ & $\mathrm{Y}$ & $\mathrm{N}$ & $\mathrm{Y}$ & $\mathrm{Y}$ \\
\hline Treatment X Year & $\mathrm{N}$ & $\mathrm{N}$ & $\mathrm{Y}$ & $\mathrm{N}$ & $\mathrm{N}$ & $\mathrm{Y}$ \\
\hline Treatment X County & $\mathrm{N}$ & $\mathrm{N}$ & $\mathrm{Y}$ & $\mathrm{N}$ & $\mathrm{N}$ & $\mathrm{Y}$ \\
\hline Observations & 1,524 & 1,524 & 1,524 & 1,522 & 1,522 & 1,522 \\
\hline R-squared & 0.975 & 0.979 & 0.986 & 0.975 & 0.979 & 0.984 \\
\hline
\end{tabular}

NOTES: The table presents results from six separate regressions of the (log) mean housing value by age. Column (1) reports results for Equation (2). Column (2) adds county-age, year-urban status, and year-age interactions. Column (3) replaces the county and decade fixed effects in Equation (2) with exemption-year and exemption-county interactions. Panel A uses the housing unit weighted average of indicator variables denoting any age-based property tax exemption in the county and covered cities. Panel B uses the inverse ratio of under 65 to over 65 simulated property taxes as the measure of the age-based property tax exemption treatment.

Robust standard errors clustered at the county level are reported in parentheses.

$* * * \mathrm{p}<0.01,{ }^{* *} \mathrm{p}<0.05, * \mathrm{p}<0.1$ 
Table 8. Percent change in mean housing value triple-difference

\begin{tabular}{lcccccc}
\hline & \multicolumn{3}{c}{ Panel A: Exemption Indicator } & \multicolumn{3}{c}{ Panel B: Simulated Tax Ratio } \\
\cline { 2 - 7 } & $(1)$ & $(2)$ & $(3)$ & $(1)$ & $(2)$ & $(3)$ \\
$\pi_{3}$ : Treatment X Older & $0.0813^{* * *}$ & $-0.0698^{*}$ & $-0.0698^{*}$ & $0.419^{* * *}$ & $-0.152^{*}$ & $-0.152^{*}$ \\
& $(0.0197)$ & $(0.0363)$ & $(0.0382)$ & $(0.0679)$ & $(0.0811)$ & $(0.0898)$ \\
$\pi_{2}$ : Treatment & $-0.131^{* * *}$ & -0.0251 & $\mathrm{~N} / \mathrm{A}$ & $-0.501^{* * *}$ & $-0.147^{*}$ & $\mathrm{~N} / \mathrm{A}$ \\
& $(0.0280)$ & $(0.0318)$ & & $(0.0637)$ & $(0.0752)$ & $\mathrm{Y}$ \\
\hline$\pi_{1}$ : Older & $\mathrm{Y}$ & $\mathrm{Y}$ & $\mathrm{Y}$ & $\mathrm{Y}$ & $\mathrm{Y}$ & $\mathrm{Y}$ \\
County FE & $\mathrm{Y}$ & $\mathrm{Y}$ & $\mathrm{Y}$ & $\mathrm{Y}$ & $\mathrm{Y}$ & $\mathrm{Y}$ \\
Year FE & $\mathrm{Y}$ & $\mathrm{Y}$ & $\mathrm{Y}$ & $\mathrm{Y}$ & $\mathrm{Y}$ & $\mathrm{Y}$ \\
County X Older & $\mathrm{N}$ & $\mathrm{Y}$ & $\mathrm{Y}$ & $\mathrm{N}$ & $\mathrm{Y}$ & $\mathrm{Y}$ \\
Year X Urban & $\mathrm{N}$ & $\mathrm{Y}$ & $\mathrm{Y}$ & $\mathrm{N}$ & $\mathrm{Y}$ & $\mathrm{Y}$ \\
Year X Older & $\mathrm{N}$ & $\mathrm{Y}$ & $\mathrm{Y}$ & $\mathrm{N}$ & $\mathrm{Y}$ & $\mathrm{Y}$ \\
Treatment X Year & $\mathrm{N}$ & $\mathrm{N}$ & $\mathrm{Y}$ & $\mathrm{N}$ & $\mathrm{N}$ & $\mathrm{Y}$ \\
Treatment X County & $\mathrm{N}$ & $\mathrm{N}$ & $\mathrm{Y}$ & $\mathrm{N}$ & $\mathrm{N}$ & $\mathrm{Y}$ \\
\hline Observations & 1,206 & 1,206 & 1,206 & 1,206 & 1,206 & 1,206 \\
R-squared & 0.707 & 0.762 & 0.792 & 0.722 & 0.765 & 0.812 \\
\hline
\end{tabular}

NOTES: The table presents results from six separate regressions of the percent change in counties, mean housing value by age. Column (1) reports results for Equation (2). Column (2) adds countyage, year-urban status, and year-age interactions. Column (3) replaces the county and decade fixed effects in Equation (2) with exemption-year and exemption-county interactions. Panel A uses the housing unit weighted average of indicator variables denoting any age-based property tax exemption in the county and covered cities. Panel B uses the inverse ratio of under 65 to over 65 simulated property taxes as the measure of the age-based property tax exemption treatment. Robust standard errors clustered at the county level are reported in parentheses.

$* * * \mathrm{p}<0.01, * * \mathrm{p}<0.05, * \mathrm{p}<0.1$ 
Table 9a. Sorting Model (Estimated Utility Parameters)

\begin{tabular}{lcc}
\hline & Panel A: Exemption Indicator & Panel B: Simulated Tax Ratio \\
\hline Treat. X Older X Owner & $0.36894^{* * *}$ & $0.39650^{* * *}$ \\
& $(0.00536)$ & $(0.01009)$ \\
\hline Treatment X Older & $-0.70251^{* * *}$ & $1.09914^{* * *}$ \\
& $(0.00501)$ & $(0.00939)$ \\
\hline Treatment X Owner & $0.05506^{* * *}$ & $0.47968^{* * *}$ \\
& $(0.00224)$ & $(0.00389)$ \\
\hline Treatment & $0.40400^{* * *}$ & $0.43116^{* * *}$ \\
& $(0.00225)$ & $(0.00396)$ \\
\hline
\end{tabular}

Table 9b. Simulated Population Changes for Cobb County, from Sorting Model

\begin{tabular}{lcccc}
\hline & $\begin{array}{c}\text { Model A: } \\
\text { Perfectly } \\
\text { Elastic Supply }\end{array}$ & $\begin{array}{c}\text { Model A: } \\
\text { Perfectly } \\
\text { Inelastic Supply }\end{array}$ & $\begin{array}{c}\text { Model B: } \\
\text { Perfectly } \\
\text { Elastic Supply }\end{array}$ & $\begin{array}{c}\text { Model B: } \\
\text { Perfectly } \\
\text { Inelastic Supply }\end{array}$ \\
\hline Change Older Owners & $-8,896$ & $-7,648$ & $-11,682$ & $-7,999$ \\
(Pct Change) & $-37.7 \%$ & $-31.6 \%$ & $-53.9 \%$ & $-34.0 \%$ \\
(As Pct of Co Pop) & $-3.8 \%$ & $-3.2 \%$ & $-5.0 \%$ & $-3.5 \%$ \\
\hline Change Young Owners & $-6,263$ & $+1,843$ & $-37,712$ & $-12,554$ \\
(Pct Change) & $-4.9 \%$ & $+1.4 \%$ & $-29.7 \%$ & $-9.0 \%$ \\
(As Pct of Co Pop) & $-2.7 \%$ & $+0.8 \%$ & $-16.3 \%$ & $-5.4 \%$ \\
\hline Change Older Renters & +95 & +526 & +111 & $+1,500$ \\
(Pct Change) & $+1.4 \%$ & $+7.8 \%$ & $+1.9 \%$ & $+22.7 \%$ \\
(As Pct of Co Pop) & $<0.1 \%$ & $+0.2 \%$ & $<0.1 \%$ & $+0.6 \%$ \\
\hline Change Younger Renters & +179 & $+5,278$ & $+1,058$ & $+19,053$ \\
(Pct Change) & $+0.2 \%$ & $+6.5 \%$ & $+1.4 \%$ & $+22.1 \%$ \\
(As Pct of Co Pop) & $<0.1 \%$ & $+2.2 \%$ & $+0.5 \%$ & $+8.2 \%$ \\
\hline
\end{tabular}


Figure 1. Population-Weighted Treatment over Time

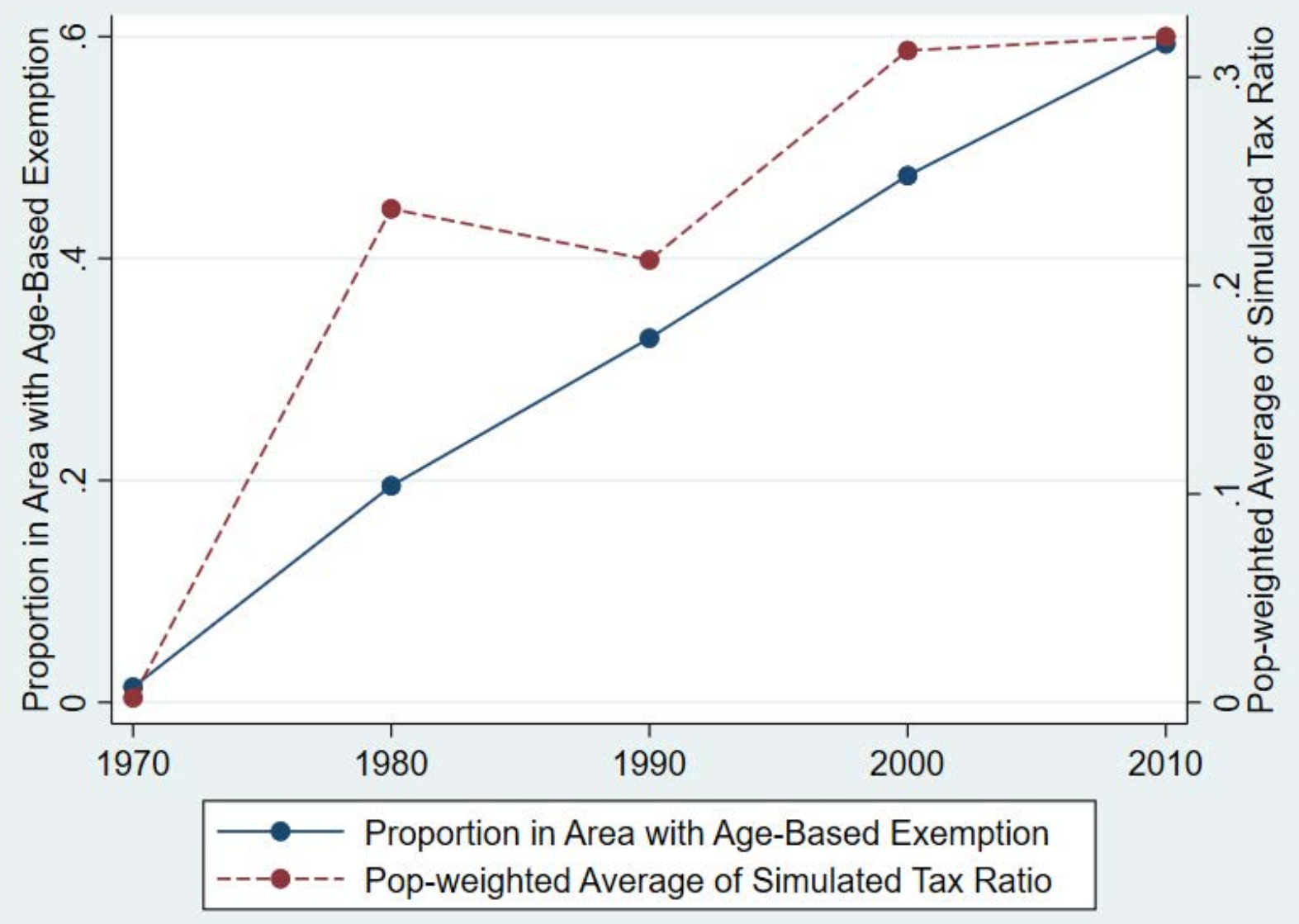


Figure 2. Event Study Analysis of the Quadruple Difference (Sun and Abraham IW Estimator)

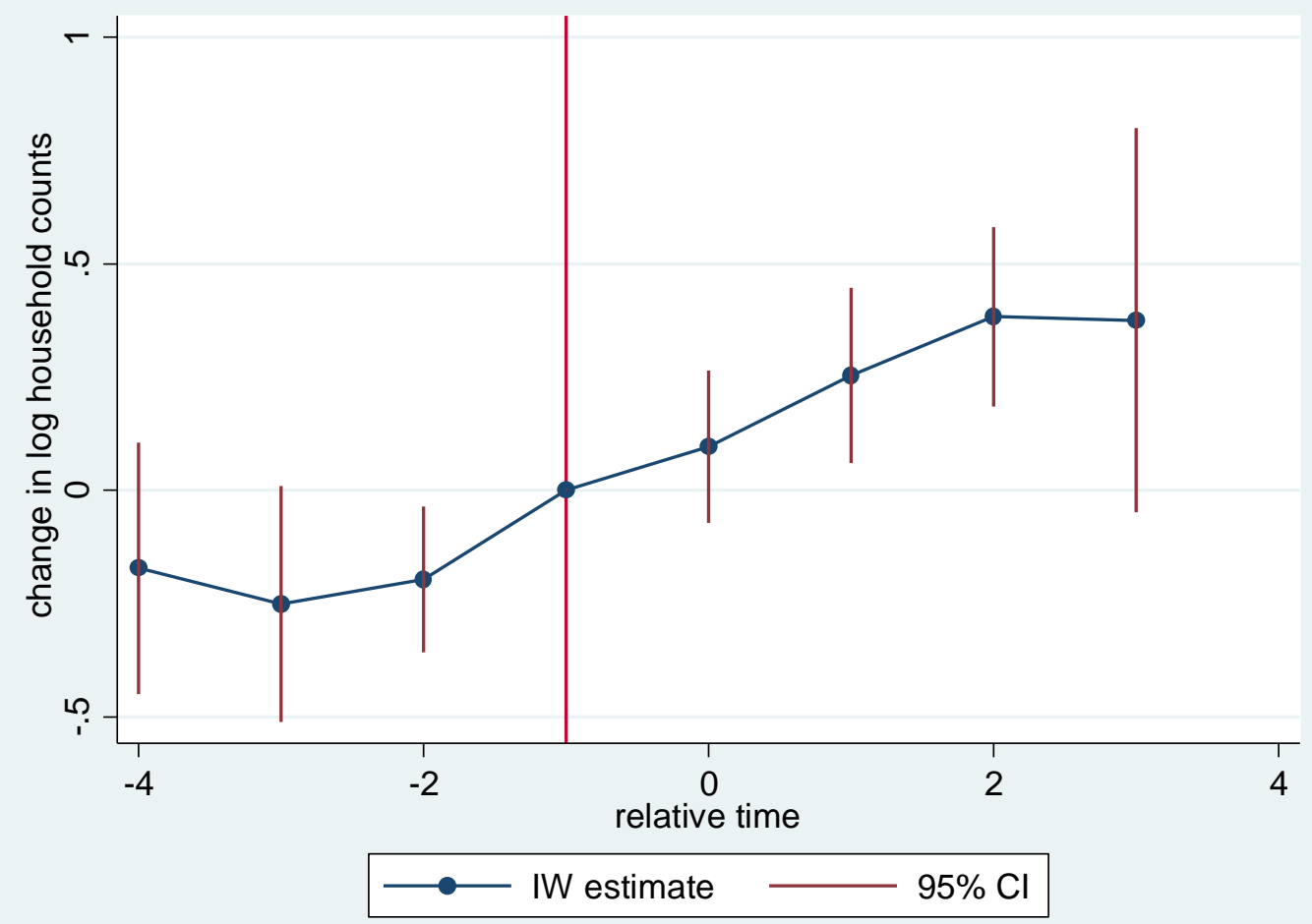

